\title{
Interactive comment on "The impact of biomass burning on upper tropospheric carbon monoxide: A study using MOCAGE global model and IAGOS airborne data" by Martin Cussac et al.
}

Martin Cussac et al.

cussacmartin@gmail.com

Received and published: 9 June 2020

Please find our answers attached in the supplement.

Please also note the supplement to this comment: https://www.atmos-chem-phys-discuss.net/acp-2019-1143/acp-2019-1143-AC2supplement.pdf 